\title{
Community social responsibility and the performance of small tourism enterprises: Moderating effects of entrepreneurs' demographics ${ }^{1}$
}

\author{
Caiping Wang ${ }^{\mathrm{a}}$, Honggang $\mathrm{Xu}^{* \mathrm{~b}}$, Gang $\mathrm{Li}^{\mathrm{c}}$, Jason $\mathrm{Li}_{\mathrm{Chen}}{ }^{\mathrm{c}}$
}

a. International School of Business \& Finance, Sun Yat-Sen University, Guangzhou, China

b. School of Tourism Management, Sun Yat-Sen University, Guangzhou, China

c. School of Hospitality and Tourism Management, University of Surrey, Guildford

$$
\text { GU2 7XH, UK }
$$

Caiping Wang, wangcp@mail.sysu.edu.cn (C. Wang), Tourism Management School, Sun Yat-sen University, No. 135, Xingang Xi Road, Guangzhou 510275, Guangdong, P. R. China, +86 20 84114584;

Honggang Xu, xuhongg@mail.sysu.edu.cn (H. Xu), <Same address with Dr. Wang>, +86 2084112891 ;

Gang Li (Corresponding author), g.li@surrey.ac.uk (G. Li), School of Hospitality and Tourism Management, University of Surrey, Guildford GU2 7XH, UK.

Jason Li Chen, 1.chen@surrey.ac.uk, School of Hospitality and Tourism Management, University of Surrey, Guildford GU2 7XH, UK.

\begin{abstract}
This study investigated the two main dimensions of STEs' community social responsibility and their impact on firms' objective and subjective performance, respectively. It also explored the moderating effects of STE owners' demographics on the relationships between the two community social responsibility dimensions and firm performance. By the survey data from STEs in the historical towns in southwestern China, the empirical findings suggested that engaging in socially responsible behavior at the community level contributes to STEs' subjective performance; and the influence of community engagement on STEs' performance is moderated by the owners' demographic characteristics, such as age, gender, ethnicity, and birthplace.
\end{abstract}

Key words: small tourism enterprises; lifestyle business; community social responsibility; upper echelons theory; China

\footnotetext{
1 This article should be cited as follows:

Wang, C., G. Li, H. Xu and L. Chen (2018). Community Social Responsibility and the Performance of Small Tourism Enterprises: Moderating Effects of Entrepreneurs' Demographics. International Journal of Tourism Research, 1-13. DOI: 10.1002/jtr.2216.
} 


\section{Introduction}

In most countries, small businesses take center stage in the tourism industry (Hallak, Assaker, and O'Connor, 2014; Font, Garay, and Jones, 2016) and play a key role in the sustainable development of tourist destinations-economically, socially, and environmentally. However, small tourism enterprises (STEs) often face great challenges to their performance or sustained success, and incur a fairly high risk of business failure (Ateljevic, 2007). Therefore, it is necessary to gain a comprehensive understanding of the various factors influencing STEs' performance.

One such factor is STEs' community social responsibility (CSR). Firms' social responsibility has been defined as "the responsibility of enterprises for their impacts on society." Enterprises should build close cooperative relationships with their stakeholders by factoring social, environmental, and other concerns into their business decisions (European Commission, 2001). The exercise of social responsibility at the community level involves cooperating with and supporting the community by offering charitable donations, establishing educational initiatives, supporting volunteer programs, and other activities (Inoue and Lee, 2011). Social responsibility is one of the most important dimensions of business (Hallak, Brown, and Lindsay, 2013; Peake, Cooper, Fitzgerald, and Muske, 2015), especially for small enterprises, due to their close connections with local communities (Peake et al., 2015).

Another important factor influencing the behaviors of small businesses is the characteristics of their owners. Upper echelons theory (UET) has been used widely to demonstrate the influence of top executives' (including owners') values and cognitive bases on their firms' strategies and performance, and executives' values are reflected in their demographic characteristics (Hambrick and Mason, 1984; Hambrick, 2007). UET may also explain the influence of owners' values and cognitive bases on the relationship between their social responsibility at the community level and their firms' performance. Whether UET can be effectively applied in a small business context has yet to be investigated. However, some authors have argued that both small businesses' CSR and their performance depend on their owners' values and cognitive bases (Carpenter, Geletkanycz, and Sanders, 2004; Pansiri, 2007).

The first aim of this study is to provide empirical evidence of the influence of STEs' CSR activities on their performance. The study extends the previous literature by dividing CSR into two dimensions and comparing their influence on STEs' performance; the performance of STEs is also categorized into objective and subjective dimensions to capture the possible divergence of small businesses' motivations in the tourism industry. Second, the study attempts to fill a gap in the literature by exploring the moderating effects of STE owners' demographic characteristics on the association between their enterprises' CSR and performance. Following Hambrick's (2007) recommendation that future researchers investigate the effects of executives' values and cognitive bases under different national systems, unique demographic characteristics such as owners' birthplace and ethnicity are included in the Chinese STE context. Testing for the indirect moderating effects of owners is also expected to contribute to the literature on UET in the strategic management field.

\section{Literature review and hypothesis development}




\section{CSR and the performance of small businesses}

To fulfil their social responsibility, firms should cooperate with their stakeholders by factoring social, environmental, and other concerns into their business decisions (European Commission, 2001). This ensures that firms' relationships with their primary stakeholders are tailored to stakeholder needs and that they exercise their social responsibility in diverse dimensions (Clarkson, 1995). Of these dimensions, the level of CSR is critical to small businesses due to their intricate relationships with the communities in which they operate (Niehm, Swinney, and Miller, 2008; Peake et al., 2015). Small tourism businesses in historical towns communicate with the community not only by providing support through charitable giving, educational initiatives, and other volunteer programs, like large companies (Inoue \& Lee, 2011), but also through their daily business cooperation in areas such as supplying materials and co-constructing community environments (Besser and Miller, 2001; Garay and Font, 2013). However, few insights have been gained into CSR, especially its influence on the performance of small tourism businesses (Niehm et al., 2008).

In the literature, almost all CSR issues have been addressed in the context of small enterprises, especially family businesses. Certain factors have been found to influence CSR. For example, Peake et al. (2015) proved that the duration of the owner's family in the community leads a firm to take more social responsibility at the community level. Besser and Miller $(2001 ; 2004)$ also found that the personal beliefs of owners and managers influenced CSR. Through cluster analysis, Besser and Miller (2001) divided 675 small business operators in 10 Iowa cities into four groups, "civic leaders, alienated business operators, followers in high collective action communities, and followers in low collective action communities," on the basis of CSR. They found that the differences between these clusters were associated with the operators' demographics and belief in the usefulness of community support strategies for business success. Business network membership has also been shown to be connected to businesses' CSR. Using a random sample of 460 nonmetro small business operators in the U.S.A., Besser, Miller, and Perkins (2006) showed that networked businesses engaged more actively in socially responsible behaviors than non-networked businesses.

The impact of CSR on firms' performance has also been emphasized in the literature. Besser and Miller (2001) reported that high levels of community support made small businesses more successful. A similar result was obtained by Niehm et al. (2008) for family-centered businesses. Using principal component analysis, they divided CSR into three dimensions: commitment to the community, community support, and sense of community (explaining $43 \%$ of the total variance). They also found that although these different dimensions had different effects on firms' performance, socially responsible behaviors at the community level generally increased the sustainability of family businesses in small rural communities. In research on small tourism businesses, community-level social responsibility has been taken only as a dimension of corporate social responsibility, in which capacity it has been shown to positively affect firms' performance (Wang, Bai, \& Xu, 2015). No attention has been paid specifically to firms' social responsibility exercised at the community level. Similarly, Gary and Font (2012) noted that firms reported above-average satisfaction with their financial performance as a result of activities such as "promoting consumption of local products" or "choosing local suppliers." To 
the best of our knowledge, however, only Hallak, Brown, and Lindsay (2013) have looked at small and medium-sized tourism enterprises' support for local communities, which they found to have positive consequences for firms' performance.

The above research in the small business context indicates that some of the personal characteristics of owners influence their firms' community-level socially responsible behaviors and the economic consequences of these behaviors. However, two significant gaps in the literature should be noted. First, most studies have taken small businesses' CSR as a whole, without exploring its diverse dimensions. Second, STEs' performance should be gauged not only by their competitiveness in the market, but also relative to the non-economic targets of their owners. An STE's objective performance can be measured by financial items reflecting the firm's survival relative to other firms in the same industry, and its subjective performance can be measured by nonfinancial items such as its owner's satisfaction or the firm's fulfillment of expectations, especially for firms with lifestyle-oriented motivations (Kropp, Lindsay, and Schoham, 2006). Both objective and subjective dimensions should be considered when measuring the performance of STEs.

This study attempts to fill these gaps in the literature by exploring STEs' CSR in depth and analyzing its various effects on firms' performance, both subjective and financial, with particular attention paid to the firm owners' characteristics.

\section{UET and owner characteristics}

UET was initially proposed by Hambrick and Mason (1984), based on bounded rationality. It generally emphasizes the influence of senior managers' characteristics on firms' strategic decisions and performance. The theory has three main tenets (Carpenter et al., 2004). First, a firm's strategic decisions reflect its top executives' values and cognitive bases; second, executives' values and cognitive bases are a function of their observable demographic characteristics, such as age, educational experience, and functional background; and third, executives' observable characteristics determine organizational decisions and outcomes (Hambrick, 2007). The use of executives' demographic characteristics as proxies for their cognitive bases and values has been shown to be valid and reliable in several research fields, although findings in this area may be incomplete (Hambrick and Mason, 1984). UET thus provides a practical method of empirical testing that circumvents the great difficulty of obtaining conventional psychometric data on top executives.

UET has been shown in many studies to explain various business strategies and the performance of large companies (Cheng, Chan, \& Leung, 2010). A few studies have concentrated on the application of the theory in the tourism industry, and the demographics of chief executive officers/top management teams have been shown to impact their risk-taking decisions (Lee and Moon, 2016), overall franchising decisions (Moon, 2015), and alliance decisions (Pansiri, 2007). Using this theory, Park, Kim, and McCleary (2014) also investigated the influence of top managers' environmental attitudes on their hotels' environmental management activities. In these studies, demographic characteristics such as gender, age, and education were used extensively. Generally, the owner of an STE is the only investor or one of the main investors in the business. The owner not only decides on the firm's daily operations (Thomas et al., 2011) but also shapes the firm's operational targets. Therefore, it is necessary to 
investigate whether and how owners' personal cognitive biases and values influence the relationship between their firms' community-wide socially responsible behaviors and business performance. UET supplies a useful theoretical basis for this study. Demographic characteristics such as gender, age, and education have been used in previous research as accurate indicators of small business owners' personal values and characteristics.

Owners' characteristics are particularly important to STEs. STEs with a lifestyle-oriented motivation have become predominant in the tourism industry (Thomas et al., 2011). The owners of these lifestyle businesses are attracted by the beautiful natural environments and relaxing atmospheres of remote rural tourist destinations, such as China's historical towns (Thomas et al., 2011). Their firms' operations are not necessarily conducted solely for profit; they may be directed toward multiple goals, such as achieving a work-life balance. Firms' different motivations may result in different socially responsible behaviors (Alcantara and Kshetri, 2014) and have different effects on their business performance. These enterprises tend to have multiple goals in their business operation, financial and nonfinancial, which are very much determined by their own subjective evaluation.

\section{Hypotheses regarding the moderating effects of owners' demographics}

In addition to the generally positive results of such activities reported in the previous literature (Besser and Miller, 2001; Hallak et al., 2013), taking social responsibility for a community has been shown to bring extra benefits for STEs. First, it helps to cushion the negative influence of management incompetence and other external shocks. For STEs, these weaknesses are generally related to high turnover and employee scarcity (Ateljevic, 2007; Manyara and Jones, 2007), over-competitive business environments (Hallak et al., 2014), and external disturbances to firms' operations. By engaging in socially responsible activities at the community level and thereby improving their communication with the community, STEs build friendship, trust, cooperation, a sense of shared vision, and their own social capital (Besser and Miller, 2001; Niehm et al., 2008). This not only creates an atmosphere conducive to healthy competition, but also helps to strengthen management competence and reduce external disturbances. Second, taking social responsibility for the community can bring emotional support for the owners of STEs. This is especially significant for lifestyle STE owners who wish to enjoy a friendly and relaxing community atmosphere. The core principle of social capital theory is that the more connections individuals make, the better off they are emotionally, socially, physically, and financially (Nicholson and Hoye, 2008). As communication increases when STEs engage in socially responsible activities, these activities can build closer relationships between STE owners and the community.

Cushioning the effects of negative incidents and/or gaining emotional support can help STE owners to overcome operational difficulties and increase their sense of achievement and satisfaction (Peake et al., 2015). But as STEs are limited by their weaknesses relative to larger-scale firms (Ateljevic, 2007) and the motivations of STEs in tourism destinations tend to be lifestyle oriented (Thomas et al., 2011), the influence of STEs' socially responsible activities at the community level on their objective performance may be relatively weak. Therefore, the following hypothesis is proposed. 
H1: Engaging in socially responsible activities at the community level significantly improves STEs' subjective performance, but has a nonsignificant influence on objective performance.

The operation of STEs is determined largely by their owners (Thomas et al., 2011). To gauge the influence of owners' personal values on their firms' operational decisions and performance, the moderating effects of owners' demographic characteristics on the associations between their firms' socially responsible behaviors on behalf of the community and their firms' performance are discussed here one by one. Relevant demographic characteristics include not only gender, age, and education, as used in the previous literature, but also birthplace and ethnicity, based on the STE characteristics observed in the initial fieldwork.

Peake et al. (2015) found gender to indirectly influence firms' participation in community-oriented social responsibility activities. Generally, people of different genders have different motivations and behaviors, according to the theory of self-construal from social psychology (Peake et al., 2015). For example, female owners tend to be more socially oriented and sensitive to ethical issues than their male counterparts (Cheng et al., 2010). They are more sensitive to others' needs and better at listening, reducing intra-group conflict, and making a good impression on their firms' stakeholders (Burgess and Tharenou, 2002). These interdependent self-construal and socially oriented merits encourage women to become involved in the community and actively pursue their social support goals. Female entrepreneurs are more likely than male entrepreneurs to start small businesses to balance their work and family lives (Hazudin et al., 2015) or to become independent and gain recognition from the community (Chu, Kara, Zhu, and Gok, 2011). Men are more concerned with achieving wealth and improving their firms' financial performance (Chen and Elston, 2013). Therefore, compared with male entrepreneurs, women obtain more satisfaction and fulfillment by engaging with the community through socially responsible activities. But their relative lack of enthusiasm for controlling business operations limits the effect of their socially responsible behaviors on their objective performance. Therefore, the following hypothesis is proposed.

H2a: The association between CSR and STEs' subjective performance is moderated by owners' gender: it is stronger if a firm's owner is female.

The age of the owner of a firm is expected to impact the firm's strategic decisions. The characteristics of older executives, such as a tendency to engage in more conservative behavior, greater risk aversion, and a greater likelihood to obey rules and routines, are thought to be consistent with the targets of CSR (Jiang, 2010). Older owners are better able to coordinate the complicated relationships within their communities by performing socially responsible activities (Legoherel et al., 2004). Through empirical testing, Besser (1999) showed that older operators provided more community support than younger operators. However, Niehm et al. (2008) found that the influence of owners' age on firms' socially responsible behaviors at community level was nonsignificant.

Many STE owners, especially middle-aged ones, are lifestyle oriented (Xu \& Ma, 2014). They usually already have good financial reserves and seek a high quality of life and the benefits of the local environment over financial performance (Morrison, 
Carlsen, and Weber, 2010; Thomas et al., 2011; Xu and Ma, 2014). They tend to enjoy a friendly local atmosphere, especially if they engage in socially responsible activities toward the community. Meanwhile, age is perceived as an indicator of valuable experience and knowledge in Chinese culture (Cheng et al., 2010). Older owners are thus significantly more likely to use their close relationships with the community to promote their businesses and increase their firms' financial performance. In contrast, engaging in socially responsible activities may be extremely costly for young STE owners, who have to fight to make a profit during the early stages of their businesses. Thus, the following hypothesis is proposed.

$H 2 b$ : The consequences of CSR for STEs' performance are stronger when firms' owners are older.

Chinese people tend to be strongly attached to their hometowns, and their "guanxi" relationships are also very much linked to their places of origin (An, 2015). This sense of attachment is deepened by the differences in language and culture between regions. Depending on their birthplace, STE owners are characterized as locals or outsiders. Compared with STE owners from other regions or provinces, local owners generally have more experience of living in the community and share the language, habits, and customs of local residents, helping them to develop a greater attachment to their communities. As Hallak et al. (2013) suggested, owners' place attachment strongly supports their family businesses' participation in community development activities, and thus local owners are more likely to receive emotional rewards and satisfaction when they forge connections with the community through active engagement at the community level. Therefore, the following hypothesis is proposed.

H2c: The association between STEs' social responsibility at the community level and their subjective performance is moderated by owners' birthplace: the association is stronger if a firm's owner is from the local area.

China's population is ethnically diverse, but the majority belongs to the Han ethnic group. For historical reasons, Han Chinese adapt to new environments faster and more easily than other minority groups (He, Zhang, and Li, 2004). In addition, Han business people have a longer tradition of working hard for profit than many of their minority counterparts (Gao, Dang, and Wan, 2013). It is thus logical to hypothesize that Han owners differ from minority owners in their business operations. Based on the literature, it is postulated that relative to owners of other ethnicities, Han owners can make greater improvements to their financial performance by engaging with the community. However, no studies have addressed the differences in operational satisfaction between Han owners and minority owners. Hence, the following hypothesis is proposed.

H2d: The association between STEs' social responsibility at the community level and their objective performance is moderated by owner ethnicity: the association is stronger if a firm's owner is Han.

Generally, a high education level reflects open-mindedness, tolerance of ambiguity, a high capacity for information processing, and risk-taking tendencies (Hambrick, 2007). A few studies have indicated that education is positively related to 
small business owners' community leadership (Besser, 1999; Besser and Miller, 2001) or to their firms' outcomes (Fairlie and Robb, 2005); however, Niehm et al. (2008) found that owners' education level was not significantly associated with small family businesses' CSR engagement. In Chinese Confucianist culture, gaining a high level of education is critical to an individual's success (Pearce, 2006). STE owners in China are thus very eager to increase their businesses' financial and nonfinancial performance to demonstrate their success. Due to these high expectations, education may have a nonsignificant or marginally significant effect on firms' performance even if better-educated STE owners more actively engage in CSR activities. Therefore, the following hypothesis is proposed

H2e: The association between STEs' CSR and performance is not moderated by the educational level of STE owners.

\section{Methodology}

This study was based on a quantitative research design. A questionnaire survey was used as the main research instrument to analyze the effect of CSR on STEs' performance and explore the moderating effects of owners' demographic characteristics.

\section{Identification of the business sector and field area}

The empirical findings were drawn from a sample of small guesthouses in China. With their beautiful scenery and profound cultural traditions, historical towns attract not only tourists but also many STEs (Xu and Ma, 2014). Our fieldwork took place in southwestern China, in the two famous towns of Dali and Yangshuo. The research team had been working in these areas for the previous several years, and had thus accumulated good knowledge of local small businesses. These towns are best known for their pioneering role in hosting international travelers in China. They were among the earliest to develop a tourism industry in the 1980s, when China "opened its door to the outside world." Due to their open business environment and leisurely atmosphere, these areas have a flourishing tourism industry, attracting not only domestic tourists, especially backpackers, but also a large number of STEs (Xu and Ma, 2014). Guesthouses make up a large proportion of the STEs in these areas (Wang et al., 2015). As they provide tourists with a full range of services, such as lodging, food, beverages, and other amenities, these guesthouses tend to have closer connections with the local community than other business entities (Wang et al., 2015). For all of these reasons, Dali and Yangshuo offered typical cases for our study.

\section{Development of the questionnaire}

The questionnaire was designed based on our review of the literature and previous work in Dali, and then tested and revised. It comprised four parts, as follows (with questionnaire items and sources shown in Table 1).

Both objective financial and subjective nonfinancial indexes were used to evaluate the performance of the sampled STEs (see Table 1). The subjective indexes were drawn mainly from Walker and Brown (2004), who developed the items with an emphasis on satisfaction to measure respondents' attitudes towards their businesses. With input from our fieldwork on STEs, two items were chosen to gauge the 
subjective dimension of STEs' performance, namely the extent to which the businesses met expectations and owners' degree of satisfaction with their jobs. The responses to these subjective items were measured on 7-point Likert scales $(1=$ not satisfactory at all and $7=$ very satisfactory). The objective performance scale was based on items proposed by Kropp et al. (2006), namely before-tax profits, return on investment (ROI), and market share. As the market share index is not suitable for use with small businesses, the percentage of repeat business was used instead to reflect the STEs' market situation. The pilot test revealed that the companies had lots of repeat tourists, especially residents of nearby areas who were attracted by the specific atmosphere of the historical towns. Based on the findings of the pilot test, we used the following scales to measure these items. For before-tax profits, $1=$ less than USD8,200 (calculated using the RMB-USD exchange rate of 6.0969, as measured on January 1,2014 ) and $5=$ over USD32,800. For ROI, $1=$ less than 5\% and $7=$ over $30 \%$. For repeat business, $1=$ less than $30 \%$ and $7=$ over $80 \%$. After responses had been provided, the items were standardized to facilitate analysis (Besser and Miller, 2001).

The items for "social responsibility at the community level" were chosen based on both the previous literature and our fieldwork. Four survey items were adopted from Besser and Miller (2001), Garay and Font (2013), and Jenkins (2006), with changes to their expression to suit the field circumstances (see Table 1). These items were as follows: purchasing materials or goods from local areas even if they were more expensive than the same or similar goods elsewhere; supporting and attending local festival events; promoting community development (through donations or support for community policies); and hiring local people. Two further items were added based on our observations of the practices of STEs in the communities under study: cooperating with the community to maintain public safety and complying with business ethics (e.g., avoiding cut-throat competition and maintaining business integrity). The responses to these items were measured on 7-point Likert scales ranging from 1 (very much disagree) to 7 (very much agree).

To test the hypotheses, general information on gender, age, and education was requested in the questionnaire. Age was divided into six 10-year ranges from "equal or younger than 20 " to "older than 60 ," and education was divided into four levels from "junior school or lower" to "Bachelor's degree or above." In addition, a question on birthplace was asked to differentiate the owners' levels of attachment to their local communities (possible responses: local area, out of town but in the same province, and outside the province). Last, to differentiate the STE owners by ethnic background (i.e., Han or minority), a question on ethnicity was included in the questionnaire.

In addition, following many previous studies (Gary and Font, 2012; Peake et al., 2015), a question on firm size was included in the questionnaire. Two indicators were used to measure size: the number of employees and the number of beds. As initial investment may also have an important influence on STEs' operational performance, a question on this was added to the questionnaire. Initial investment was measured on a 5-point scale ranging from 1 (less than about USD16,400) to 5 (over about USD65,607). 


\begin{tabular}{|c|c|}
\hline Categories \& Items & Source \\
\hline \multicolumn{2}{|l|}{ Sustainable operation } \\
\hline Realizing business expectations & \multirow{3}{*}{$\begin{array}{l}\text { Walker and Brown's (2004), and revised or } \\
\text { reworded according to field work. }\end{array}$} \\
\hline Degree of satisfaction for current job & \\
\hline Tendency to operate the business for a long time & \\
\hline Before tax profits & \multirow{2}{*}{ Kropp, Lindsay, and Schoham (2006) } \\
\hline Return on investment (ROI) & \\
\hline Percent of repeat business & \multirow[t]{2}{*}{ Modified from Kropp et al. (2006) } \\
\hline Social responsibility towards community & \\
\hline Trying to buy materials or goods locally, even if they cost more & \multirow{3}{*}{$\begin{array}{l}\text { Besser and Miller (2001); Font and Garay } \\
(2014)\end{array}$} \\
\hline $\begin{array}{l}\text { Supporting and attending important local social or festival } \\
\text { events }\end{array}$ & \\
\hline $\begin{array}{l}\text { Promoting community development (e.g., donating or executing } \\
\text { community proposals) }\end{array}$ & \\
\hline Hiring employees from the community & Jenkins (2006) \\
\hline Cooperating with the community to keep public security & \\
\hline $\begin{array}{l}\text { Complying with business ethics (avoiding cut-throat } \\
\text { competition and operating with business integrity) }\end{array}$ & Fieldwork \\
\hline
\end{tabular}

\section{Data collection and analysis methods}

The survey was conducted with the owners of the STEs due to their significant roles in the firms' operations (Font et al., 2016). A pilot test with 10 STEs in Dali was carried out first. The STE owners were asked to fill out the survey and provide feedback on item wording and the overall design of the survey instrument. Based on the respondents' feedback and other comments, the research team made further revisions to the questionnaire, with an emphasis on rewording some of the items derived from previous research. The formal fieldwork was carried out in Dali from July 25 to August 15, 2013 and in Yangshuo from January 9 to February 10, 2014. The sample totaled 154 responses (47 from Dali and 107 from Yangshuo).

Regression analysis was used to gauge the extent to which STEs' social responsibility at the community level influenced their business performance. Model 1 was proposed as a baseline model:

$$
\text { Perf }=\alpha+\beta \operatorname{Res} L C+\sum_{i} \theta_{i} \text { control }_{i}+\varepsilon,
$$

where Perf refers to STE performance in objective and subjective dimensions; ResLC refers to CSR; and the control variables (control $)_{\text {) comprise } L n E m p l}$ and LnBed, the natural logarithms of the STEs' number of employees and number of beds respectively, and InInvest, the value of the STEs' initial investment. In Model 1, $\alpha$ is a constant, $\beta$ and $\theta_{i}$ are the regression coefficients, and $\varepsilon$ is the error term. To avoid endogeneity, effective empirical methods and survey data analysis tools were chosen and verified (Zhou, 2005).

As discussed in the literature review, owners' demographic characteristics are likely to affect STEs' performance, and demographic characteristics may also moderate the effect on performance of STEs' CSR engagement. To capture these direct and interactive effects, a set of demographic variables $\left(D C_{i}\right)$ and interactive terms $\left(\operatorname{Res} L C \times D C_{i}\right)$ were introduced in Model 2:

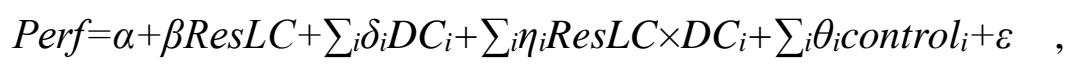

where the $D C_{i}$ variables comprise gender, age, education, ethnicity, and birthplace. 
Before running the regression analysis, the measurement items for CSR were subjected to exploratory factor analysis to detect the dimensionality of the construct, and the factor scores derived were used as the independent variable $\operatorname{ResLC}$ in the regression models. Once multiple dimensions of CSR had been identified, they were entered into the models as separate independent variables to enable us to capture and compare the effects of different CSR dimensions on performance.

However, using factor scores estimated by regression as dependent variables may generate biased slope coefficients (Skrondal and Laake, 2001). As a solution, plausible values (Asparouhov and Muthén, 2010) were produced for the objective and subjective dimensions of performance. This approach treats a latent variable as an observed variable with missing values. A multiple imputation method (Rubin, 1987) was used to impute the missing values $m$ times, which resulted in $m$ completed sets of the latent variable. Each of these $m$ sets was then regressed separately. Finally, the results of the $m$ regressions were pooled to give one result. As a larger number of imputations may produce more powerful significance tests (Enders, 2010), $m$ was set at 100.

\section{Empirical results and discussion}

\section{Demographics of respondents}

Most of the STE owners were between 20 and 60 years old; 21-30 was the largest age group (44.81\%), followed by 31-40 (33.77\%). Fewer than half of the STE owners were locals (42.48\%), with nonlocals comprising a majority (57.52\%). Of the nonlocals, $69.32 \%$ (equivalent to $39.87 \%$ of the whole sample) were from outside nearby provinces. The STE owners were generally well educated, with $31.33 \%$ holding Bachelor's degrees or higher, and another $25.33 \%$ with college-level education. In terms of ethnicity, most of the STE owners were Han (70.78\%). The gender distribution was almost equal. A summary of the demographics of the STE owners is provided in Table 2.

Table 2 Demographics of STE owners

\begin{tabular}{llcc}
\hline Variable & Categories & Frequency & Percent \\
\hline Age & $\leq 20$ & 5 & $3.25 \%$ \\
& $21-30$ & 69 & $44.81 \%$ \\
& $31-40$ & 52 & $33.77 \%$ \\
& $41-50$ & 24 & $15.58 \%$ \\
& $51-60$ & 3 & $1.95 \%$ \\
& $\geq 60$ & 1 & $0.64 \%$ \\
\hline Birthplace & Local area & 65 & $42.48 \%$ \\
& Out of town but in the same province & 27 & $17.65 \%$ \\
& Out of the province & 61 & $39.87 \%$ \\
\hline Education & Junior school or lower & 19 & $12.67 \%$ \\
& High school & 46 & $30.67 \%$ \\
& College degree & 38 & $25.33 \%$ \\
& Bachelor's degree or higher & 47 & $31.33 \%$ \\
\hline Ethnicity & Han & 109 & $70.78 \%$ \\
& Minority & 35 & $29.22 \%$ \\
\hline Gender & Male & 76 & $49 \%$ \\
& Female & 73 & $51 \%$ \\
\hline Note. "Local area" means that the owner comes from the historical town in which the STE is located. In China, a \\
college degree requires three years and a university degree requires four years. The sample sizes for different \\
variables are different because of missing data. & &
\end{tabular}




\section{Dimensions of CSR}

Factor analysis was run to examine the dimensionality of the STEs' CSR engagement. The result of Bartlett's sphericity test was significant at the 0.05 level, and the Kaiser-Meyer-Olkin value was 0.70, greater than the acceptance threshold of 0.5 . Therefore, factor analysis was suitable for the study. Next, as the initial eigenvalues were greater than 1, two factors/dimensions were extracted using the principal component method of factor analysis. These two dimensions represented two ways in which the STEs fulfilled their responsibility for the community: by engaging in important community events, i.e., community engagement; and through daily activities, i.e., operational support (see Table 3). Unlike the methods used in previous literature (Besser \& Miller, 2001; Niehm et al., 2007), our factor analysis yielded dimensions based on the possible frequency of CSR activities. Our first dimension, community engagement $\left(C_{S R}\right)$, represented STEs' demonstration of social responsibility by participating in important events such as festivals or making donations to support community development. The STEs engaged less frequently in these socially responsible behaviors, first due to their resource constraints (Hallak et al., 2013) and second due to the voluntary nature of the activities. Unlike the first dimension, the second dimension, operational support $\left(C S R_{o s}\right)$, included daily operational activities likely to provide support for community development. Our fieldwork revealed that these activities were executed most frequently by most of the STEs because they had few employees and required special resources from the community (such as architectural ornaments and local food).

Table 3 Exploratory factor analysis of social responsibility towards community

\begin{tabular}{|c|c|c|c|c|}
\hline Factor: Scale Items and Scale Reliability & Mean & S.D. & $\begin{array}{c}\text { Factor } \\
\text { Loading }\end{array}$ & Eigenvalue \\
\hline \multicolumn{4}{|c|}{ Factor 1 Community engagement: demonstrating responsibility by important activities $(\alpha=0.732)$; } & 2.346 \\
\hline $\begin{array}{l}\text { percent of variance explained }=39.103 \% \text {. } \\
\text { Supporting and attending important local } \\
\text { social festival events }\end{array}$ & 5.623 & 1.210 & 0.861 & \\
\hline $\begin{array}{l}\text { Promoting community development } \\
\text { (donating or executing community } \\
\text { proposals) }\end{array}$ & 5.591 & 1.302 & 0.848 & \\
\hline \multicolumn{4}{|c|}{$\begin{array}{l}\text { Factor } 2 \text { Operational support: demonstrating responsibility by daily activities }(\alpha=0.545) \text {; } \\
\text { percent of variance explained }=16.986 \% \text {. }\end{array}$} & 1.091 \\
\hline $\begin{array}{l}\text { Trying to buy material or goods locally even } \\
\text { though this will cost more }\end{array}$ & 3.506 & 1.614 & 0.556 & \\
\hline Hiring employees from the community & 5.403 & 1.350 & 0.686 & \\
\hline $\begin{array}{l}\text { Cooperating with the community to keep } \\
\text { public security }\end{array}$ & 6.240 & 0.984 & 0.574 & \\
\hline $\begin{array}{l}\text { Complying with business ethics (avoiding } \\
\text { cut-throat competition, and operating with } \\
\text { business integrity) }\end{array}$ & 6.545 & 0.908 & 0.662 & \\
\hline
\end{tabular}

\section{CSR and STEs' performance}

Before assessing the impact of CSR on STEs' subjective and objective performance, descriptive statistical analysis was executed. Both a t-test and analysis of variance were used to compare the relationship between firms' CSR and their performance as categorized by the moderating variables $\left(D C_{i}\right)$ of the STE owners' demographics. Overall, significant differences were found for three of the five demographic variables shown in Table 4. First, subjective performance was found to differ between male and 
female owners $(\mathrm{t}=2.089)$. Second, CSR behavior at the community level was found to vary significantly between groups divided by owner's birthplace or educational level. For example, the overall difference between the groups categorized by birthplace was significant $(\mathrm{F}=4.409, \mathrm{p}<0.05)$, as shown in Part B of Table 4. Part A of Table 4 also shows that the mean value of $C S R_{c e}$ for firms with local owners was significantly higher than that for firms with owners from other places. These differential effects of demographic characteristics support the use of UET in a Chinese context. The moderating effects of the demographic variables hypothesized in this study were further tested in the regression models.

Next, the correlations between the explanatory variables were analyzed, and the findings are presented in Table 5. Strong correlations were found between the two age variables, Age low $30_{0}$ and Age $_{31-40}(r=-0.687, p<0.01)$, and between the two birthplace variables, $B P_{\text {local }}$ and $B P_{\text {outprov }}(r=-0.692, p<0.01)$. We thus assessed the variance inflation factors for each empirical model, and found all to be lower than 3 , well below the commonly adopted rule of thumb of 10 . Multicollinearity was thus not a serious concern in our study.

Table 4

Differences for STEs community social responsibility and performance with different owner demographics

\begin{tabular}{|c|c|c|c|c|c|c|c|c|}
\hline \multicolumn{9}{|c|}{ Part A: T-test } \\
\hline \multirow{2}{*}{ Variables } & \multirow{2}{*}{ Category } & \multicolumn{2}{|c|}{ Value $=1$} & \multicolumn{2}{|c|}{ Value $=0$} & \multirow{2}{*}{\multicolumn{2}{|c|}{ Mean difference (1-2) }} & \multirow{2}{*}{ T-Value } \\
\hline & & Mean(1) & STD & Mean(2) & STD & & & \\
\hline Sub-perf & Gender & 0.183 & 1.205 & -0.282 & 1.238 & & & $2.089^{* * *}$ \\
\hline \multirow[t]{2}{*}{$\mathrm{CSR}_{\mathrm{ce}}$} & $\mathrm{BP}_{\text {Local }}$ & 0.272 & 0.828 & -0.199 & 1.070 & & & $3.079^{* * *}$ \\
\hline & $\mathrm{BP}_{\text {outprov }}$ & -0.176 & 1.137 & 0.115 & 0.887 & & & $1.782^{*}$ \\
\hline \multirow{2}{*}{$\mathrm{CSR}_{\mathrm{ce}}$} & Edulowcoll & -0.181 & 1.051 & 0.176 & 0.936 & & & $-2.193^{* *}$ \\
\hline & Edubach & 0.299 & 0.923 & -0.131 & 1.008 & & & $2.587^{* *}$ \\
\hline \multicolumn{9}{|c|}{ Part B: ANOVA Test-Post hoc } \\
\hline Variables & Groups & \multicolumn{2}{|c|}{ Comparing(I-J) } & \multicolumn{2}{|c|}{$\begin{array}{l}\text { Mean } \\
\text { difference(I-J) }\end{array}$} & Sig. & $\mathrm{F}$ & Sig. \\
\hline \multirow[t]{3}{*}{$\mathrm{CSR}_{\text {ce }}$} & 1. GBPLocal & \multicolumn{2}{|l|}{1 and 2} & \multicolumn{2}{|l|}{$0.521^{*}$} & 0.051 & & \\
\hline & 2. $\mathrm{GBP}_{\text {inprov }}$ & \multicolumn{2}{|l|}{1 and 3} & \multicolumn{2}{|l|}{$0.448^{* * *}$} & 0.030 & $4.409^{* *}$ & 0.014 \\
\hline & 3. $\mathrm{GBP}_{\text {outprov }}$ & \multicolumn{2}{|l|}{2 and 3} & \multicolumn{2}{|l|}{-0.073} & 0.943 & & \\
\hline \multirow[t]{3}{*}{$\mathrm{CSR}_{\mathrm{ce}}$} & 1. GEdu lowcoll & \multicolumn{2}{|l|}{1 and 2} & \multicolumn{2}{|l|}{-0.132} & 0.789 & & \\
\hline & 2. GEdu coll & \multicolumn{2}{|l|}{1 and 3} & \multicolumn{2}{|l|}{$-.479^{*}$} & 0.032 & $3.319^{* *}$ & 0.039 \\
\hline & 3. GEdubach & \multicolumn{2}{|l|}{2 and 3} & \multicolumn{2}{|l|}{-0.348} & 0.239 & & \\
\hline
\end{tabular}

Note: This table lists only the significant results for CSR and performance categorized by different demographics. In Part A, Gender is a dummy variable coded 1 for male and 0 for female; Edubach is an education dummy variable coded 1 for bachelor's degree or higher, and 0 otherwise; Edulowcoll is another dummy variable for education, coded 1 for education lower than the college level, i.e., high school and lower; $B P_{\text {Local }}$ is a dummy variable for STE owners' birthplace, coded 1 for local historical town, and 0 otherwise; BP Outprov is coded 1 if the owner is from another province. These dummy variables are used for the regression tests. In Part B, GBP Local, GBP inprov and GBPoutprov represent STE owners' groups from the local town, the local province but not the local town, or other provinces respectively; GEdu lowcoll, GEdu coll $_{\text {and GEdubach }}$ represent STEs owners with only high school or a low education degree, college, or bachelor's degree respectively. Only the results from the Tukey HSD method are listed in Part B. These results are consistent with ones tested by other methods. *, **, *** represent significant results at the $0.10,0.05$, and 0.01 confidence levels, respectively. This is the same for following tables. 
Table 5 Means, standard deviations, and correlations

\begin{tabular}{|c|c|c|c|c|c|c|c|c|c|c|c|c|c|c|c|}
\hline Variables & Mean & SD & $\mathrm{CSR}_{\mathrm{ce}}$ & $\mathrm{CSR}_{\mathrm{os}}$ & Lnemploy & lnbed & Invest & Gender & Ethnicity & Age $_{\text {low30 }}$ & Age $_{31-40}$ & Edu $_{\text {lowcoll }}$ & Edubach & $\mathrm{BP}_{\text {local }}$ & $\mathrm{BP}_{\text {outpro }}$ \\
\hline$\overline{\mathrm{CSR}_{\mathrm{ce}}}$ & 0 & 1 & 1.000 & & & & & & & & & & & & \\
\hline $\mathrm{CSR}_{\mathrm{os}}$ & 0 & 1 & 0.000 & 1.000 & & & & & & & & & & & \\
\hline lnemploy & 1.296 & 0.561 & 0.044 & -0.022 & 1.000 & & & & & & & & & & \\
\hline lnbed & 3.243 & 0.723 & -0.001 & -0.067 & $0.527^{* * * *}$ & 1.000 & & & & & & & & & \\
\hline Invest & 0.550 & 0.499 & $0.144^{*}$ & 0.031 & $0.256^{* * * *}$ & 0.132 & 1.000 & & & & & & & & \\
\hline Gender & 0.510 & 0.502 & -0.004 & 0.079 & -0.114 & 0.044 & -0.016 & 1.000 & & & & & & & \\
\hline Ethnicity & 0.770 & 0.420 & -0.006 & -0.108 & 0.017 & 0.105 & 0.004 & -0.038 & 1.000 & & & & & & \\
\hline Agelow30 & 0.480 & 0.501 & -0.046 & -0.107 & $0.139^{*}$ & 0.033 & 0.091 & 0.021 & -0.068 & 1.000 & & & & & \\
\hline Age $_{31-40}$ & 0.340 & 0.474 & 0.078 & 0.068 & -0.085 & -0.026 & -0.029 & $-0.198^{* *}$ & 0.060 & $-0.687^{* * * *}$ & 1.000 & & & & \\
\hline Edulowcoll & 0.450 & 0.499 & $-0.160^{* *}$ & 0.007 & -0.104 & -0.010 & $-0.156^{*}$ & 0.063 & $-0.135^{*}$ & $-0.213^{* * * *}$ & -0.008 & 1.000 & & & \\
\hline Edu $_{\text {bach }}$ & 0.310 & 0.462 & $0.199^{* *}$ & -0.001 & 0.051 & -0.087 & $0.281^{* * *}$ & -0.013 & $0.191^{* *}$ & $0.181^{* *}$ & -0.026 & $-0.597^{* * * *}$ & 1.000 & & \\
\hline $\mathrm{BP}_{\text {local }}$ & 0.420 & 0.496 & $0.233^{* * *}$ & 0.071 & 0.003 & 0.097 & $-0.139^{*}$ & -0.031 & $-0.227^{* * * *}$ & -0.059 & 0.001 & $0.367^{\text {**** }}$ & $-0.338^{* * * *}$ & 1.000 & \\
\hline $\mathrm{BP}_{\text {outpro }}$ & 0.400 & 0.491 & $-0.143^{*}$ & -0.097 & -0.030 & $-0.186^{* *}$ & 0.028 & 0.011 & $0.249^{\text {**** }}$ & 0.045 & -0.017 & $-0.383^{* * *}$ & $0.328^{* * *}$ & $-0.692^{* * *}$ & 1.000 \\
\hline
\end{tabular}

Note: Ethnicity is a dummy variable, coded 1 for Han ethnicity and 0 for other minorities; Agelow 30 is an age dummy variable coded 1 if the age is equal or low than 30 , and 0 otherwise; Age $31-40$

is another dummy variable for age, coded 1 for the range 31-40, and 0 otherwise. The other variables are consistent with the ones introduced in Table 4 . 
Lastly, based on the results of the factor analysis, two dimensions of CSR, CSR $R_{c e}$ and $C S R_{o s}$, were included as the main independent variables in Models 1 and 2. Table 5 shows the pooled results of the regressions. The $F$-statistics of all of the models except Model 1 were significant at the 0.05 level. Models 1 and 6 were the benchmark models, containing only control variables. In Models 2 and 7, we included the main effects of the two social responsibility variables. For Model 2, with subjective performance as the dependent variable, the coefficient of $C S R_{c e}$ was 0.296 , significant at the 0.01 level, and that of $C S R_{o s}$ was nonsignificant; but for Model 7, with objective performance as the dependent variable, the coefficients of both $C S R_{c e}$ and $C S R_{o s}$ were nonsignificant. These results showed that STEs' engagement with the community through participation in community events was likely to improve their subjective performance in dimensions such as fulfilling owners' expectations or delivering job satisfaction, but that such CSR activities did not necessarily improve the STEs' objective financial performance. Therefore, $\mathrm{H} 1$ was supported.

\section{The moderating effects of STE owners' demographics}

The moderating effects of the STE owners' demographic characteristics were tested in Models 3-5 and 8-10. Table 6 lists only the significant moderators of the relationship between the STE owners' community responsibility and their firms' performance. In line with Aiken and West (1991), interaction plots describing the moderating roles of the variables are provided in Figures 1a to 1f.

Models 3, 4, and 5 predicted subjective performance, and Models 8, 9 and 10 included objective performance as the dependent variable. The coefficient of CSRce $\times$ Gender for Model 3 was -0.525 , significant at the 0.05 level. The nonsignificant difference between male and female STE owners' CSR activities (see Table 4) indicates that female owners are more likely to realize targets such as balancing their work and family lives and gaining greater recognition from local society (Hazudin, etc., 2015; Chu, et al., 2011), and that they receive more satisfaction by exercising their social responsibility at the community level (see Figure 1a). This empirically supported Hypothesis 2a, which predicted that gender would have a significant moderating effect, with a positive influence exerted by female owners. In addition, as shown in Table 6, the positive influence of gender on firms' objective and subjective performance indicates that male owners are more likely to achieve their financial targets without considering their firms' CSR (Chen and Elston, 2013).

The findings for the two main age groups, 31-40 (Age 31-40) and $\leq 30$ (Agelow30), are listed for Models 4, 9, and 10. In Model 4, the coefficient of CSRce $\times A g e_{31-40}$ was found to be significant $(0.570, p<0.05)$. This indicates that compared with those from other age groups, STE owners aged between 31 and 40 are able to obtain greater job satisfaction by engaging with the community (see Figure 1b). The negative moderating effect of Age low30 was evidenced by the coefficient of CSRce $\times A g e_{\text {low } 30}$ $(-0.208, p<0.05)$ in Model 9. The coefficient of CSRce $\times$ Age $31-40$ was 0.213, significant at the 0.1 level, in Model 10. Compared with STE owners aged under 30, those aged between 31 and 40 gained bigger improvements to their financial performance by engaging with the community (see Figure 1e and 1f). Overall, these findings are consistent, and may be due to the nature of older STE owners' operational targets and their richer experience, as discussed in Hypothesis 3. Thus, Hypothesis $2 \mathrm{~b}$ was supported. 
A significant result was also obtained for $B P_{\text {outprov }}$ in Model 5. The interaction of $C S R c e \times B P_{\text {outprov }}$ was -0.555 , significant at the 0.05 level, showing that owners' being from another province decreased the effect of firms' community engagement activities on their subjective performance. Combined with the slope of the line observed in Figure 1c, this finding supported Hypothesis $2 \mathrm{c}$. In addition, $B P_{\text {Local }}$ and $B P_{\text {outprov }}$ in Model 5 were both significantly negative, implying that although owners' stronger local identity may help to increase the positive influence of community engagement on their STEs' subjective performance (Table 4), local owners may also have a higher expectation of business success, which is more difficult to satisfy. In addition, the coefficient $B P_{\text {local }}$ in Model 8 was positive. This implies that compared with owners from other provinces, local owners achieve better objective financial performance due to their local knowledge and networks.

In Model 8, with objective performance as the dependent variable, the coefficient of the interaction CSRce $\times$ Ethnicity was 0.339 ( $p<0.05)$. Accompanying the negative main effect of CSRce $(-0.276, p<0.1)$, this implies that compared with owners belonging to ethnic minority groups, Han owners of STEs enjoy larger increments in financial performance as a result of community engagement (Figure 1d). This finding is consistent with Hypothesis $2 \mathrm{~d}$.

Hypothesis 2e was also supported, because education was not empirically found to have a significant moderating influence. The control variable Lnemploy had a significantly positive influence on STEs' financial performance in Models 8 to 10 . According to Raju and Lonial (2002), having a greater number of employees helps to increase firms' revenue. Ininvest was also found to have a positive influence in most of the models. A larger initial investment indicates a better financial ability, helping to reduce STEs' financial pressure and improve their performance. 
Table 6 Pooled results of regressions

\begin{tabular}{|c|c|c|c|c|c|c|c|c|c|c|}
\hline \multirow{2}{*}{ Variables } & \multicolumn{5}{|c|}{ Subjective performance } & \multicolumn{5}{|c|}{ Objective performance } \\
\hline & (1) & (2) & (3) & (4) & (5) & (6) & (7) & (8) & (9) & (10) \\
\hline Intercept & $\begin{array}{c}0.724 \\
(1.228)\end{array}$ & $\begin{array}{c}0.820 \\
(1.412)\end{array}$ & $\begin{array}{c}1.183 \\
(1.436)\end{array}$ & $\begin{array}{c}1.086 \\
(1.319)\end{array}$ & $\begin{array}{c}1.465^{*} \\
(1.769)\end{array}$ & $\begin{array}{c}-0.281 \\
(-1.050)\end{array}$ & $\begin{array}{c}-0.226 \\
(-0.842)\end{array}$ & $\begin{array}{c}-0.330 \\
(-0.868)\end{array}$ & $\begin{array}{c}-0.398 \\
(-1.041)\end{array}$ & $\begin{array}{c}-0.354 \\
(-0.928)\end{array}$ \\
\hline Lnemploy & $\begin{array}{c}-0.144 \\
(-0.576)\end{array}$ & $\begin{array}{c}-0.143 \\
(-0.581)\end{array}$ & $\begin{array}{c}-0.070 \\
(-0.273)\end{array}$ & $\begin{array}{c}-0.075 \\
(-0.293)\end{array}$ & $\begin{array}{c}-0.080 \\
(-0.315)\end{array}$ & $\begin{array}{c}0.168 \\
(1.508)\end{array}$ & $\begin{array}{c}0.175 \\
(1.585)\end{array}$ & $\begin{array}{l}0.234^{* *} \\
(2.044)\end{array}$ & $\begin{array}{c}0.215^{*} \\
(1.869)\end{array}$ & $\begin{array}{c}0.211^{*} \\
(1.838)\end{array}$ \\
\hline Lnbed & $\begin{array}{c}-0.265 \\
(-1.402)\end{array}$ & $\begin{array}{c}-0.263 \\
(-1.411)\end{array}$ & $\begin{array}{l}-0.351^{*} \\
(-1.800)\end{array}$ & $\begin{array}{l}-0.334^{*} \\
(-1.712)\end{array}$ & $\begin{array}{l}-0.366^{*} \\
(-1.881)\end{array}$ & $\begin{array}{c}-0.055 \\
(-0.647)\end{array}$ & $\begin{array}{c}-0.070 \\
(-0.829)\end{array}$ & $\begin{array}{c}-0.115 \\
(-1.307)\end{array}$ & $\begin{array}{c}-0.100 \\
(-1.133)\end{array}$ & $\begin{array}{c}-0.101 \\
(-1.142)\end{array}$ \\
\hline Ininvest & $\begin{array}{c}0.329 \\
(1.397)\end{array}$ & $\begin{array}{c}0.235 \\
(1.004)\end{array}$ & $\begin{array}{c}0.148 \\
(0.605)\end{array}$ & $\begin{array}{c}0.134 \\
(0.548)\end{array}$ & $\begin{array}{c}0.090 \\
(0.366)\end{array}$ & $\begin{array}{l}0.218^{* *} \\
(2.048)\end{array}$ & $\begin{array}{c}0.208^{*} \\
(1.945)\end{array}$ & $\begin{array}{l}0.230^{* *} \\
(2.090)\end{array}$ & $\begin{array}{l}0.263^{* *} \\
(2.384)\end{array}$ & $\begin{array}{l}0.244^{* *} \\
(2.218)\end{array}$ \\
\hline $\mathrm{CSR}_{\mathrm{ce}}$ & & $\begin{array}{c}0.296^{* * *} \\
(2.583)\end{array}$ & $\begin{array}{c}0.566^{* * *} \\
(3.215)\end{array}$ & $\begin{array}{c}0.086 \\
(0.577)\end{array}$ & $\begin{array}{c}0.570^{* * *} \\
(3.288)\end{array}$ & & $\begin{array}{c}0.059 \\
(1.125)\end{array}$ & $\begin{array}{c}-0.276^{*} \\
(-1.763)\end{array}$ & $\begin{array}{c}0.115 \\
(1.602)\end{array}$ & $\begin{array}{c}-0.051 \\
(-0.727)\end{array}$ \\
\hline $\mathrm{CSR}_{0 \mathrm{~S}}$ & & $\begin{array}{c}0.038 \\
(0.359)\end{array}$ & $\begin{array}{c}0.007 \\
(0.062)\end{array}$ & $\begin{array}{c}0.028 \\
(0.262)\end{array}$ & $\begin{array}{c}0.021 \\
(0.196)\end{array}$ & & $\begin{array}{c}-0.065 \\
(-1.355)\end{array}$ & $\begin{array}{c}-0.075 \\
(-1.551)\end{array}$ & $\begin{array}{c}-0.075 \\
(-1.537)\end{array}$ & $\begin{array}{c}-0.074 \\
(-1.531)\end{array}$ \\
\hline Gender & & & $\begin{array}{c}0.606^{* * *} \\
(2.665)\end{array}$ & $\begin{array}{c}0.590^{* * *} \\
(2.600)\end{array}$ & $\begin{array}{l}0.515^{* *} \\
(2.244)\end{array}$ & & & $\begin{array}{c}0.275^{* * *} \\
(2.607)\end{array}$ & $\begin{array}{c}0.276^{* * *} \\
(2.641)\end{array}$ & $\begin{array}{l}0.242^{* *} \\
(2.334)\end{array}$ \\
\hline Ethnicity & & & $\begin{array}{c}-0.197 \\
(-0.680)\end{array}$ & $\begin{array}{c}-0.087 \\
(-0.300)\end{array}$ & $\begin{array}{c}-0.262 \\
(-0.899)\end{array}$ & & & $\begin{array}{c}-0.068 \\
(-0.523)\end{array}$ & $\begin{array}{c}-0.032 \\
(-0.241)\end{array}$ & $\begin{array}{c}-0.032 \\
(-0.247)\end{array}$ \\
\hline Edu lowcoll & & & $\begin{array}{c}0.372 \\
(1.157)\end{array}$ & $\begin{array}{c}0.218 \\
(0.697)\end{array}$ & $\begin{array}{c}0.248 \\
(0.794)\end{array}$ & & & $\begin{array}{c}0.078 \\
(0.572)\end{array}$ & $\begin{array}{c}0.070 \\
(0.509)\end{array}$ & $\begin{array}{c}0.088 \\
(0.638)\end{array}$ \\
\hline$E_{\text {duach }}$ & & & $\begin{array}{c}0.525 \\
(1.623)\end{array}$ & $\begin{array}{c}0.371 \\
(1.162)\end{array}$ & $\begin{array}{c}0.391 \\
(1.226)\end{array}$ & & & $\begin{array}{c}0.148 \\
(1.017)\end{array}$ & $\begin{array}{c}0.093 \\
(0.642)\end{array}$ & $\begin{array}{c}0.098 \\
(0.675)\end{array}$ \\
\hline $\operatorname{Age}_{\text {low30 }}$ & & & $\begin{array}{c}-0.298 \\
(-0.988)\end{array}$ & $\begin{array}{c}-0.316 \\
(-1.049)\end{array}$ & $\begin{array}{c}-0.220 \\
(-0.732)\end{array}$ & & & $\begin{array}{c}-0.214 \\
(-1.499)\end{array}$ & $\begin{array}{c}-0.210 \\
(-1.465)\end{array}$ & $\begin{array}{c}-0.227 \\
(-1.582)\end{array}$ \\
\hline $\operatorname{Age}_{31-40}$ & & & $\begin{array}{c}-0.236 \\
(-0.726)\end{array}$ & $\begin{array}{c}-0.229 \\
(-0.707)\end{array}$ & $\begin{array}{c}-0.111 \\
(-0.337)\end{array}$ & & & $\begin{array}{c}-0.132 \\
(-0.896)\end{array}$ & $\begin{array}{c}-0.113 \\
(-0.767)\end{array}$ & $\begin{array}{c}-0.108 \\
(-0.735)\end{array}$ \\
\hline$B P_{\text {Local }}$ & & & $\begin{array}{c}-0.440 \\
(-1.399)\end{array}$ & $\begin{array}{c}-0.371 \\
(-1.183)\end{array}$ & $\begin{array}{l}-0.551^{*} \\
(-1.729)\end{array}$ & & & $\begin{array}{c}0.245^{*} \\
(1.737)\end{array}$ & $\begin{array}{c}0.228 \\
(1.619)\end{array}$ & $\begin{array}{c}0.229 \\
(1.622)\end{array}$ \\
\hline BP outprov & & & $\begin{array}{c}-0.552^{*} \\
(-1.661)\end{array}$ & $\begin{array}{c}-0.429 \\
(-1.296)\end{array}$ & $\begin{array}{l}-0.588^{*} \\
(-1.763)\end{array}$ & & & $\begin{array}{c}0.045 \\
(0.289)\end{array}$ & $\begin{array}{c}0.026 \\
(0.167)\end{array}$ & $\begin{array}{c}0.008 \\
(0.048)\end{array}$ \\
\hline $\mathrm{CSR}_{\mathrm{ce}} \times \mathrm{Gender}$ & & & $\begin{array}{l}-0.525^{* *} \\
(-2.240)\end{array}$ & & & & & & & \\
\hline $\mathrm{CSR}_{\mathrm{ce}} \times$ Ethnicity & & & & & & & & $\begin{array}{l}0.339^{* *} \\
(2.057)\end{array}$ & & \\
\hline $\mathrm{CSR}_{\text {ce }} \times \mathrm{Age}_{\mathrm{low} 30}$ & & & & & & & & & $\begin{array}{l}-0.208^{* *} \\
(-1.977)\end{array}$ & \\
\hline $\mathrm{CSR}_{\text {ce }} \times \mathrm{Age}_{31-40}$ & & & & $\begin{array}{l}0.570^{* *} \\
(2.348)\end{array}$ & & & & & & $\begin{array}{c}0.213^{*} \\
(1.907)\end{array}$ \\
\hline $\mathrm{CSR}_{\text {ce }} \times \mathrm{BP}_{\text {outprov }}$ & & & & & $\begin{array}{l}-0.555^{* *} \\
(-2.335)\end{array}$ & & & & & \\
\hline Observations & 115 & 115 & 109 & 109 & 109 & 115 & 115 & 109 & 109 & 109 \\
\hline $\mathrm{R}^{2}$ & 0.048 & 0.104 & 0.228 & 0.231 & 0.231 & 0.109 & 0.145 & 0.325 & 0.320 & 0.320 \\
\hline Adjusted $R^{2}$ & 0.022 & 0.063 & 0.113 & 0.117 & 0.116 & 0.084 & 0.104 & 0.224 & 0.218 & 0.218 \\
\hline F-statistic & 1.870 & $2.537^{* *}$ & $1.974^{* *}$ & $2.018^{* *}$ & $2.012^{* *}$ & $2.922^{* *}$ & $2.461^{* *}$ & $1.958^{* *}$ & $2.051^{* *}$ & $2.041^{* *}$ \\
\hline
\end{tabular}

Note. Only the results with significant moderating effects are listed. The variations of observation numbers are due to the missing data with different variables (performance, demographic and control variables) included different the regression models. Variance inflation factor (VIF) measures were used to confirm that there is no sign of multicollinearity. Following Aiken and West (1991), mean-centered treatment was applied on CSRce to avoid multicollinearity between Ethnicity and CSR $R_{c e}$ variables. T-values are listed in parentheses. 


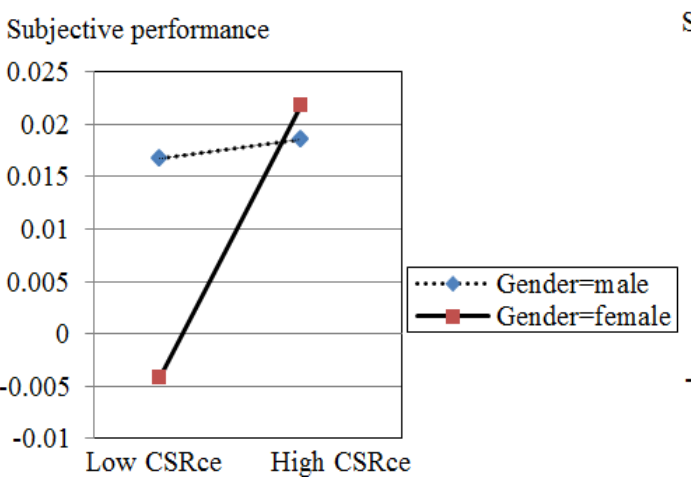

(a)

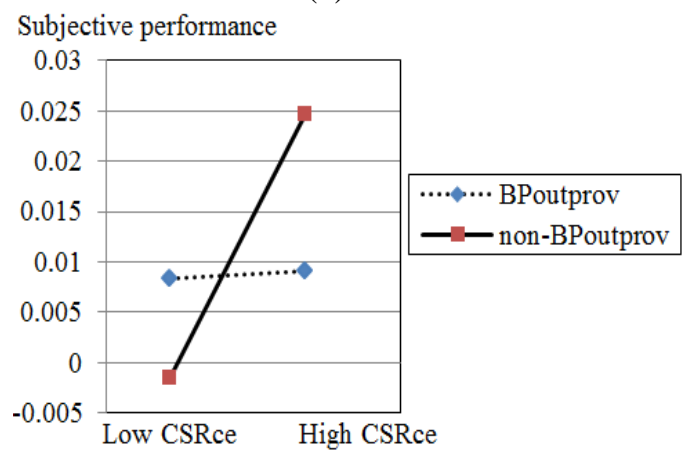

(c)

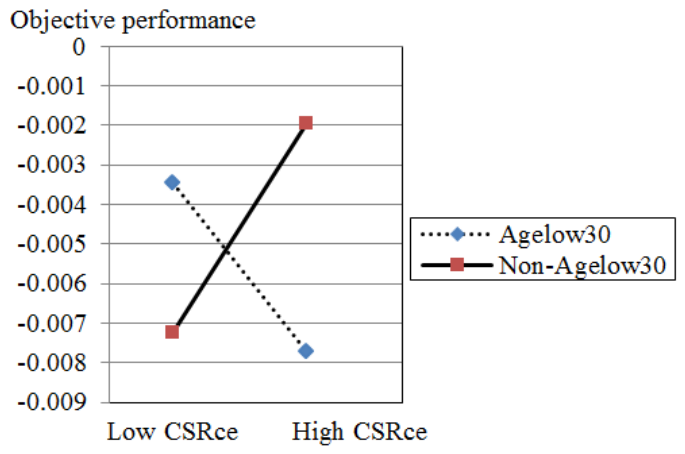

(e)

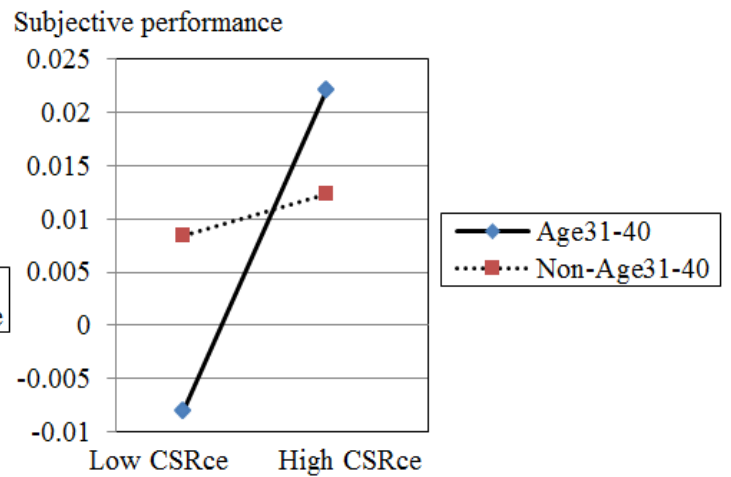

(b)

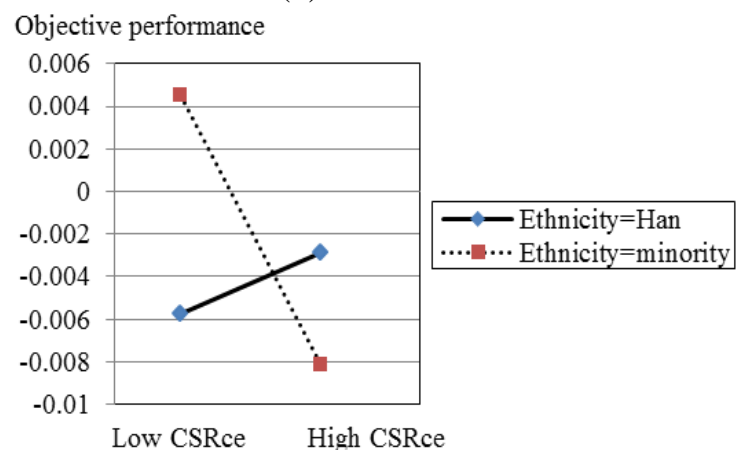

(d)

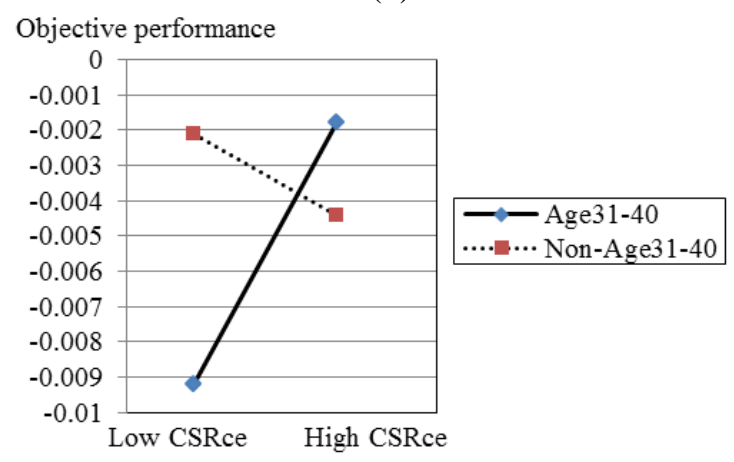

(f)

Fig. 1.

Moderating effects of STE owners' demographics

\section{Conclusions and limitations}

\section{Discussion and conclusion}

In the context of small tourism businesses, this study investigated the association between CSR and firms' performance in depth, and explored the moderating effects of business owners' demographics on this association based on UET. Using data obtained from fieldwork on small tourism guesthouses in historical towns in southwestern China, social responsibility at the community level was first divided into two dimensions, community engagement (through participation in community events) and daily operational support. Similarly, firms' performance was measured in two dimensions: objective and subjective.

The study obtained several interesting findings. First, the descriptive statistics revealed significant differences in firms' community engagement and subjective performance between groups categorized by STE owners' demographic 
characteristics, such as educational level, birthplace, and gender. Second, the results of the regression analysis show that the exercise of social responsibility through community engagement can improve STEs' subjective performance, but that daily operational support for the community has no significant influence on either firms' subjective performance or their objective performance. Last, and most importantly, demographic variables such as gender, age, ethnicity, and birthplace were found to have moderating effectss, but only on the influence of community engagement on STEs' performance. The moderating effect of education was proved to be nonsignificant in the context of STEs in China.

The different findings for the two dimensions of CSR may be related to the characteristics of STEs in historical towns. In practice, due to the limited labor market and to support the local community, most STEs tend to hire locals as employees. Meanwhile, STE owners readily become familiar with each other in such small tourist towns (Besser, 2012). Thus, STE owners who engage in unethical business practices will not only experience financial losses but also gain a poor reputation within the community. This threat encourages them to pursue ethical business practices in their daily operations. In addition, STEs often try to provide services reflecting the specific features and traditions of the local areas (Qiu \& Bao, 2005). In the historical towns surveyed in this study, such services emphasized the local architectural style and/or food. The STEs also sought to buy materials in the local area where possible. All of these factors made support for the community necessary for STEs, not simply dependent on their owners' characteristics. In contrast, community engagement through donations or attendance at social festivals was found to be flexible, resting primarily on the STE owners' personal values (Hambrick, 2007). The differences between STE owners moderated the influence of community engagement on their firms' subjective performance.

\section{Contribution and limitations}

Only limited research has been conducted on the use of UET to explain tourism-related decisions (Lee and Moon, 2016; Park et al., 2014), and this theory has never been linked with CSR decisions in a small business context. This study contributes to the strategic management literature by applying UET in the unique context of small tourism businesses, offering the following fresh evidence in support of UET. First, the differences in CSR and performance between groups with different demographics provide further evidence of the effectiveness of this theory. Second, the study promotes the development of UET by revealing the specific indirect moderating effects of owners' demographic characteristics. Third, the findings for ethnicity and birthplace enlarge the range of relevant executive background characteristics discussed in the previous literature on applications of UET. Hambrick (2007) emphasized the need to explore the various effects of executive background under different national systems, and the current study provides new evidence of the relevance not only of traditional demographic characteristics, such as gender, age, and education, but also the unique features of Chinese STE owners.

As well as promoting the use of UET, this study contributes to the CSR and small business literature. First, the division of CSR into two dimensions enhances understanding of the multidimensional nature of this concept and the different effects of these dimensions on firms' performance. Community engagement and operational support have different effects on the performance of small tourism businesses in 
historical towns. Meanwhile, due to fierce competition, the financial margins of micro-enterprises are small, making it more important for owners to build sustainable businesses than to increase their financial gains. The findings on the moderating effects of STE owners' demographic characteristics also enrich the community-oriented social responsibility literature on both tourism and small businesses in general.

In terms of its practical implications, this study proposes an effective way for small tourism businesses to increase their success: engaging in socially responsible behaviors within their local communities. To build more stable social connections between STEs and their communities, public policies should be formulated to encourage small tourism business owners to participate in local community activities. To facilitate this process, some of the background characteristics of STE owners should be kept in mind due to their influence on owners' tendency to engage in socially responsible activities. All of these initiatives are expected not only to help STEs improve their performance or become successful, but also to contribute to the economic revitalization and sustainable development of destinations.

The fieldwork for this study took place in two similar historical towns selected to ensure a good degree of sample homogeneity. In the future, comparative research using samples from different types of destinations will provide a more comprehensive understanding of STEs' CSR behavior in relation to their performance. In addition, this study focused only on small guesthouses; further research should be conducted in other service sectors to obtain more generalizable findings.

\section{Acknowledgement}

This work was supported by China National Social Science Foundation under Grant (17BGL116).

\section{References}

Asparouhov, T., \& Muthén, B. (2010). Plausible values for latent variables using Mplus. Technical Report. Los Angeles, CA: Muthén \& Muthén.

Aiken, L. S., \& West, S. G. (1991). Multiple regression: Testing and interpreting interactions. Thousand Oaks, CA: Sage Publications.

An, D. M. (2015). Objectified nostalgia: The "hometown" conception and expression in Chinese traditional folklore ethnography. Folk Culture Forum, 231(2): 5-10.

Alcantara, L. L., \& Kshetri, N. (2013). The link between societal motivation and new venture performance: Evidence from entrepreneurs in Japan. Journal of Small Business \& Entrepreneurship, 26(6): 623-641.

Ateljevic, J. (2007). Small tourism firms and management practices in New Zealand: The center stage macro region. Tourism Management, 28: 307-316.

Besser, T. L. (1999). Community involvement and the perception of success among small business operators in small towns. Journal of Small Business Management, July, 16-29.

Besser, T. L., \& Miller, N. (2001). Is the good corporation dead? The community 
social responsibility of small business operators. Journal of Socio-Economics, 33: 221-241.

Besser, T. L., \& Miller, N. (2004). The risks of enlightened self-interest: Small businesses and support for community. Business and Society, 43(4): 398-425.

Besser, T. L., Miller, N., \& Perkins, R. K. (2006). For the greater good: Business networks and business social responsibility to communities. Entrepreneurship \& Regional Development, 18(4), 321-339.

Besser, T. L. (2012). The consequences of social responsibility for small business owners in small towns. Business Ethics: A European Review, 21(2): 129-139.

Burgess, Z., \& Tharenou, P. (2002). Women board directors: Characteristics of the few. Journal of Business Ethics, 37(1): 39-49.

Carpenter, M. A., Geletkanycz, M. A., \& Sanders, W. G. (2004). Upper echelons research revisited: Antecedents, elements, and consequences of top management team composition. Journal of Management, 30(6): 749-778.

Cheng, T. W. L., Chan, Y. K. R., \& Leung, T. Y. (2010). Management demography and corporate performance: Evidence from China. International Business Review, 19: 261-275.

Chen, S. C., \& Elston, J. K. (2013). Entrepreneurial motives and characteristics: An analysis of small restaurant owners. International Journal of Hospitality Management, 35(35): 294-305.

Chu, H. M., Kara, O., Zhu, X. W., \& Gok, K. (2011). Chinese entrepreneurs: Motivations, success factors, problems, and business-related stress. Journal of Chinese Entrepreneurship, 3(2): 84-111.

Clarkson, M. B. E. (1995). A stakeholder framework for analyzing and evaluating corporate social performance. The Academy of Management Review, 20(1): 92-117.

Enders, C. K. (2010). Applied missing data analysis. New York, NY: The Guilford Press.

European Commission. (2011). Corporate social responsibility (CSR). https://ec.europa.eu/growth/industry/corporate-social-responsibility_en.

Fairlie, R. W., \& Robb, A. M. (2005). Families, human capital, and small business: Evidence from the characteristics of business owners survey. Discussion Paper CES 05-07, Center for Economic Studies, Bureau of the Census, Washington, DC.

Font, X., Garay, L. \& Jones, S. (2016). Sustainability motivations and practices in small tourism enterprises in European protected areas. Journal of Cleaner Production, 137(20): 1439-1448.

Garay L.T., \& Font, X. (2012). Doing good to do well? Corporate social responsibility reasons, practices and impacts in small and medium accommodation enterprises. International Journal of Hospitality Management, 31(2): 329-337.

Garay, L. T., \& Font, X. (2013). Corporate social responsibility in tourism small and medium enterprises evidence from Europe and Latin America. Tourism Management Perspectives, 7: 38-46.

Gao, C. H., Dang, B. B., \& Wan, M. G. (2013). A comparative study of stereotypes between Han and minority college students. Journal of Northwest Normal University (Social Sciences), 50(4): 106-110.

Hambrick, D. C., \& Mason, P. A. (1984). Upper echelons: The organization as a reflection of its top managers. The Academy of Management Review, 9(2): 193-206.

Hambrick, D. C. (2007). UET: An update. Academy of Management Review, 32(2), 334-343.

Hallak, R., Brown, G., \& Lindsay, N. J. (2013). Examining tourism SME owners' place attachment, support for community and business performance: The role of the 
enlightened self-interest model. Journal of Sustainable Tourism, 21(5): 658-678.

Hallak, R., Assaker, G., \& O'Connor, P. (2014). Are family and nonfamily tourism businesses different? An examination of the entrepreneurial self-efficacy-entrepreneurial performance relationship. Journal of Hospitality \& Tourism Research, 38(3), 388-413.

Hazudin, S. F., Kader, M., Tarmuji, N. H., Ishak, M., \& Ali, R. (2015). Discovering small business start-up motives, success factors and barriers: A gender analysis. Procedia Economics and Finance, 31, 436-443.

He, Y., Zhang, Q. L., \& Li, H. (2004). Investigation on the learning adaptation of minority and the Han nationality undergraduate students. Journal of Southwest China Normal University (Humanities and Social Sciences Edition), 33(3): 44-47.

Inoue, Y., \& Lee, S. (2011). Effects of different dimensions of corporate social responsibility on corporate financial performance in tourism-related industries. Tourism Management, 32 (4): 790-804.

Jenkins, H. (2006). Small business champions for corporate social responsibility. Journal of Business Ethics, 67: 241-256.

Jiang, Z. (2010). Determinant of corporate social performance: From the perspective of upper echelon theory. International Conference on Information Management, 2: 418-420.

Kropp, F., Lindsay, N. J. \& Schoham, A. (2006). Entrepreneurial, market, and learning orientations and international entrepreneurial business venture performance in South African firms. International Marketing Review, 23(5): 504-523.

Legoherel, P., Callo, P., Gallopel, K., \& Peters, M. (2004). Personality characteristics, attitudes towards risk, and decisional orientation of the small business entrepreneur: a study of hospitality managers. Journal of Hospitality \& Tourism Research, 28:109-120.

Lee, W. S., \& Moon, J. (2016). Determinants of CEO strategic risk-taking in the airline industry. Tourism Management Perspectives, 18: 111-117.

Manyara, G., \& Jones, E. (2007). Community-based tourism enterprises development in Kenya: An exploration of their potential as avenues of poverty reduction”. Journal of Sustainable Tourism, 15(6): 628-644.

Moon, J. (2015). Franchising and top management team (TMT) decisions in the US restaurant industry. A Dissertation on Hotel, Restaurant and Institutional Management, The Pennsylvania State University.

Morrison, A., Carlsen, J., \& Weber, P. (2010). Small business research change and evolution. International Journal of Tourism Research, 12(6): 739-749.

Niehm, L. S., Swinney, J., \& Miller, N. J. (2008). Community social responsibility and its consequences for family business performance". Journal of Small Business Management, 46: 331-350.

Nicholson, M., \& Hoye, R. (2008). Sport and social capital. Oxford: Elsevier.

Park, J., Kim, H. J., \& McCleary, K. W. (2014). The impact of top management's environmental attitudes on hotel companies' environmental management. Journal of Hospitality \& Tourism Research, 38(1): 95-115.

Pansiri, J. (2007). How company and managerial characteristics influence strategic alliance adoption in the travel sector. International Journal of Tourism Research, 9(4): 243-255.

Pearce, R. R. (2006). Effects of cultural and social structural factors on the achievement of white and Chinese American students at school transition points. American Educational Research Journal, 43 (1):75-101.

Peake, O. E., Cooper, D., Fitzgerald, M. A., \& Muske, G. (2015). Family business 
participation in community social responsibility: The moderating effect of gender. Journal of Business Ethics, 19(June): 1-19.

Qiu, J. Q., \& Bao, J.G. (2005). A study progress on oversea small tourism businesses. Tourism Tribune, 20(5): 86-92.

Raju, P. S., \& Lonial, S. C. (2002). The impact of service quality and marketing on financial performance in the hospital industry: An empirical examination. Journal of Retailing and Consumer Services, 9: 335-348.

Rubin, D. B. (1987). Multiple imputation for nonresponse in surveys. New York, NY: John Wiley \& Sons.

Skrondal, A., \& Laake, P. (2001). Regression among factor scores. Psychometrika, 66(4), 563-575.

Thomas, R., Shaw, G. \& Page, S. J. (2011). Understanding small firms in tourism: A perspective on research trends and challenges. Tourism Management, 32(5): 963-976.

Walker, E., \& Brown, A. (2004). What success factors are important to small business owners?. International Small Business Journal, 22(6): 577-594.

Wang, C. P., Bai, B. Y. \& Xu, H. G. (2015). Influences of corporate social responsibility on sustainable operation of small tourism enterprises located at heritage sites in China. Tourism Tribune, 30(9): 25-33.

$\mathrm{Xu}$, H. G., \& Ma, S. Y. (2014). Regional environment of destination and the entrepreneurship of small tourism businesses: A case study of Dali and Lijiang of Yunnan province. Asia Pacific Journal of Tourism Research, 19(2): 144-161.

Zhou, Y. B. (2005). Social capital: A review of theoretic and empirical literatures. Economic Review, 6: 120-125. 